\title{
PENERAPAN METODE SINGLE MOVING AVERAGE UNTUK PERAMALAN HARGA CABAI RAWIT HIJAU
}

\author{
Astrid Novita Putri' ${ }^{1}$, Anindya Khrisna Wardhani \\ ${ }^{1}$ Universitas Semarang, ${ }^{2}$ Universitas Diponegoro \\ Email: ${ }^{1}$ astrid@usm.ac.id, ${ }^{2}$ nindywardhani77@gmail.com
}

(Naskah masuk: 10 Desember 2020, diterima untuk diterbitkan: 29 Desember 2020)

\begin{abstract}
Abstrak
Harga cabai yang kurang menentu dan bahkan cenderung terus mengalami kenaikan pada beberapa waktu tertentu akan berakibat buruk. Oleh karena itu informasi naik turunnya harga cabai pada waktu-waktu sebelumnya, dapat menjadi variable baru yang dipertimbangkan dalam peramalan harga cabai. Melihat permasalahan tersebut di harapkan metode single moving average dapat digunakan dengan baik untuk memprediksi fluktuasi tren harga cabai, sebagai langkah antisipasi permintaan pasar. Penelitian ini bertujuan untuk membandingkan metode single moving average dengan menggunakan ordo yang berbeda. Pada metode Single Moving Average berordo 10 didapatkan nilai $\mathrm{e}_{\mathrm{t}}$ 199.600, MSE 7.677 dan RMSE 14.12799. Sedangkan metode Single Moving Average berordo 5 didapatkan nilai $\mathrm{e}_{\mathrm{t}}$ 118.200, MSE 3.813 dan RMSE 10.87198. Dari tersebut, diantara dua metode yang digunakan dalam peramalan harga cabai di Kota Semarang dengan mengunakan metode Single Moving Average berordo 5 dan Single Moving Average berordo 10, terbukti bahwa metode Single Moving Average berordo 5 lebih baik dibandingkan dengan metode Single Moving Average berordo 10.
\end{abstract}

Kata kunci: single moving average, time series, MSE, RMSE

\section{APPLICATION OF SINGLE MOVING AVERAGE METHOD FOR PRICE FORECASTING GREEN CAYENNE PEPPER}

\begin{abstract}
The price of chili that is uncertain and even tends to continue to increase at certain times will have bad consequences. Therefore, information on the ups and downs of chili prices at previous times can be a new variable to be considered in forecasting chili prices. Seeing these problems, it is expected that the single moving average method can be used properly to predict fluctuations in the price of chilies, as a measure to anticipate market demand. This study aims to compare the single moving average method using different orders. In the Single Moving Average method with order of 10, et values are obtained. 199,600, MSE 7,677, RMSE 14,12799. While the Single Moving Average method with order of 5 obtained et values 118,200, MSE 3,813 and RMSE 10.87198. From this, between the two methods used in forecasting chili prices in the city of Semarang by using the Single Moving Average method with order of 5 and Single Moving Average with order of 10, it is proven that the Single Moving Average method with order of 5 is better than the Single Moving Average method with order of 10.
\end{abstract}

Keywords: single moving average, time series, MSE, RMSE

\section{PENDAHULUAN}

Peranan pemasaran pada komoditas cabai memberikan kontribusi penting dalam peningkatan kinerja usaha tani komoditas cabai secara keseluruhan mengingat sifat unik komoditas hortikultura secara umum seperti mudah busuk, mudah rusak, volumenious, produksinya bersifat musiman sementara konsumsi terjadi sepanjang tahun (Sukmawati, 2014)

Cabai merah merupakan salah satu komoditas yang memiliki fluktuasi harga yang cukup besar. Fluktuasi harga cabai merah dapat disebabkan oleh besarnya jumlah penawaran dan besarnya jumlah permintaan. Semakin tinggi jumlah penawaran maka harga akan rendah, sedangkan semakin sedikitnya jumlah penawaran harga akan semakin meningkat (ceteris paribus). Harga cabai merah yang sangat fluktuatif menjadikan komoditas ini sulit untuk dapat diprediksi ( Musrhalis , 2007)

Guncangan pada produksi dan konsumsi akan menyebabkan keragaman harga. Keragaman produksi disebabkan karena keragaman di lokasi pertanaman dan keragaman hasil biasanya karena cuaca. Keragaman konsumsi disebabkan karena 
perubahan pendapatan, perubahan harga komoditas substitusi, dan pergeseran selera (Gilbert and Morgan 2010). Guncangan ini menyebabkan volatilitas harga di pasar, di mana pasar tidak bisa secara otomatis menstabilkan guncangan harga yang terjadi. Oleh karena itu, diperlukan intervensi pemerintah untuk meningkatkan kepekaan petani terhadap perubahan pasar (Huffaker,dkk. 2016).

Harga cabai yang kurang menentu dan bahkan cenderung terus mengalami kenaikan pada beberapa waktu tertentu akan berakibat buruk. Oleh karena itu informasi naik turunnya harga cabai pada waktuwaktu sebelumnya, dapat menjadi variable baru yang dipertimbangkan dalam peramalan harga cabai. Melihat permasalahan tersebut di harapkan metode single moving average dapat digunakan dengan baik untuk memprediksi fluktuasi tren harga cabai, sebagai langkah antisipasi permintaan pasar (Hadiansyah, 2017).

Metode single moving average adalah suatu metode peramalan yang dilakukan dengan mengambil sekelompok nilai pengamatan, mencari nilai rata-rata tersebut sebagai ramalan untuk periode yang akan datang (Subagyo, 2008). Metode Single Moving Average mempunyai karakteristik khusus yaitu untuk menentukan ramalan pada periode yang akan datang memerlukan data historis selama jangka waktu tertentu. Selain itu, semakin panjang jangka waktu single moving average, efek pelicinan semakin terlihat dalam ramalan atau menghasilakan moving average yang semakin halus.

Pada penelitian sebelumnya, metode moving average digunakan dalam peramalan jumlah mahasiswa pada jurusan Teknik Informatika di UPN Veteran Yogyakarta. Metode yang digunakan untuk melakukan peramalan jumlah mahasiswa adalah metode Moving Average yang akurasinya dihitung menggunakan akurasi peramalan Mean Square Error (MSE), Mean Absolute Error (MAE) dan Mean Absolute Percentage Error (MAPE) untuk memilih model terbaik yang akan digunakan untuk peramalan.

Metode Moving Average juga digunakan dalam sistem informasi peramalan pembelian stok barang. Dengan adanya sistem menggunakan metode moving average, dapat membantu dan mempermudah dalam penentuan berapa pembelian stok barang diperiode selanjutnya (Solikin, 2016).

Berdasarkan penelitian sebelumnya, metode single moving average akan diteliti untuk implementasi dalam menentukan peramalan harga cabai rawit hijau. Selain digunakan untuk meramalkan harga cabai rawit hijau, penelitian ini bertujuan untuk membandingkan metode single moving average dengan menggunakan ordo yang berbeda.

\section{METODE}

\subsection{Single Moving Average}

Single Moving Average (SMA) atau Rata - rata bergerak Tunggal adalah nilai rata-rata yang tidak tertimbang dari $\mathrm{n}$ data sebelumnya atau dengan kata lain sebuah teknik yang merata-ratakan sebuah angka dari nilai aktual terbaru, diperbaharui sebagai nilainilai baru yang tersedia. Rumus yang digunakan adalah sebagai berikut :

$\mathrm{SMA}=\mathrm{M}_{\mathrm{t}}=\mathrm{M}_{\mathrm{t}}=\mathrm{M}_{\mathrm{t}+1}=\frac{Y t+Y t-1+Y t-2+\cdots Y t-n-1}{n}$

dimana :

$\mathrm{M}_{\mathrm{t}}=$ Moving average untuk periode $\mathrm{t}$

$\mathrm{F}_{\mathrm{t}+1}=$ Ramalan untuk periode $\mathrm{t}+1$

$\mathrm{Y}_{\mathrm{t}}=$ Nilai riil periode ke $\mathrm{t}$

\subsection{Pengukuran Akurasi Hasil Peramalan}

Beberapa metode telah digunakan untuk menunjukkan kesalahan yang disebabkan oleh suatu teknik peramalan tertentu. Hampir semua ukuran tersebut menggunakan pengrata-rataan beberapa fungsi dari perbedaan antara nilai sebenarnya dengan nilai peramalannya. Perbedaan nilai sebenarnya dengan nilai peramalan ini biasanya disebut sebagai residual. Persamaan menghitung nilai error asli atau residual dari setiap periode peramalan adalah sebagai berikut (Subagyo, 2002):

$e_{t}=X_{t}-S_{t}$

Dimana,

et $=$ Kesalahan peramalan pada periode $\mathrm{t}$.

$\mathrm{Xt}=$ Data pada periode $\mathrm{t}$.

$\mathrm{St}=$ Nilai peramalan pada periode $\mathrm{t}$.

Selain itu, terdapat perhitungan akurasi menggunakan metode root mean square eror (RMSE). Root Mean Square Error (RMSE) merupakan besarnya tingkat kesalahan hasil prediksi, dimana semakin kecil (mendekati 0) nilai RMSE maka hasil prediksi akan semakin akurat. Nilai RMSE dapat dihitung dengan persamaan sebagai berikut :

$$
\text { RMSE }=\sqrt{\frac{\Sigma(X-Y)^{2}}{n}}
$$

Dimana :

$\mathrm{X}=$ nilai hasil observasi

$\mathrm{Y}=$ nilai hasil prediksi

$\mathrm{n}=$ jumlah data

Metode lain untuk perhitungan akurasi adalah Mean Square Eror. Jika terdapat nilai pengamatan dan peramalan untuk $\mathrm{n}$ periode waktu, maka akan terdapat $\mathrm{n}$ buah kesalahan dan ukuran statistik standar yang dapat didefinisikan salah satunya dengan ratarata kuadrat kesalahan (Mean Squared Error atau $M S E$ ). MSE merupakan metode alterntif untuk mengevaluasi teknik peramalan masing-masing kesalahan (selisih data aktual terhadap data peramalan) dikuadratkan, kemudian dijumlahkan dan dibagi dengan jumlah data. MSE dihitung dengan rumus : 
$\operatorname{MSE}=\sqrt{\frac{\sum_{i=1}^{n} e_{i}^{2}}{n}}$

dimana,

$\mathrm{e}_{\mathrm{i}}=$ kesalahan peramalan pada periode $\mathrm{i}$

$\mathrm{n}=$ jumlah data

\section{PEMBAHASAN DAN HASIL}

\subsection{Sample Data}

Sampel yang digunakan harga cabai rawit hijau di Kota Semarang dengan sumber Dinas Pertanian Kota Semarang. Jenis data yang disajikan adalah data harian dengan rentang waktu 10 Juni - 31 Juli 2019.

Tabel 1. Sample Data Harga Cabai Rawit Hijau

\begin{tabular}{cc}
\hline Periode & Harga Cabai Rawit Hijau \\
\hline 10 Juni 2019 & 28.000 \\
11 Juni 2019 & 28.000 \\
12 Juni 2019 & 28.000 \\
13 Juni 2019 & 28.000 \\
14 Juni 2019 & 28.000 \\
17 Juni 2019 & 28.000 \\
18 Juni 2019 & 28.000 \\
19 Juni 2019 & 28.000 \\
20 Juni 2019 & 30.000 \\
24 Juni 2019 & 30.000 \\
25 Juni 2019 & 30.000 \\
26 Juni 2019 & 30.000 \\
27 Juni 2019 & 26.000 \\
28 Juni 2019 & 26.000 \\
01 Juli 2019 & 26.000 \\
02 Juli 2019 & 26.000 \\
\hline
\end{tabular}

\subsection{Hasil Penelitian}

Hasil dari penelitian ini adalah untuk membandingkan orde yang lebih baik untuk digunakan. Dari masing - masing orde 5 dan orde 10 didapatkan hasil analisa, dimana data dijadikan sebagai input untuk masing-masing model sehingga nilai-nilai prediksi akan keluar sebagai output dari masing-masing model tersebut. Pada Gambar 1 dan Gambar 2 di tunjukkan hasil dari prediksi masingmasing model yang dibandingkan dengan data observasi yang asli.

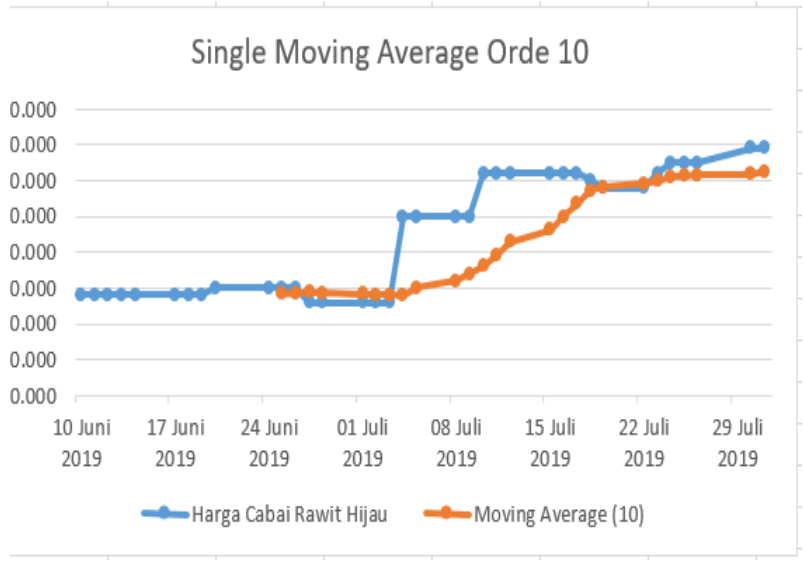

Gambar 2. Perbandingan data observasi dengan hasil peramalan berorde 10

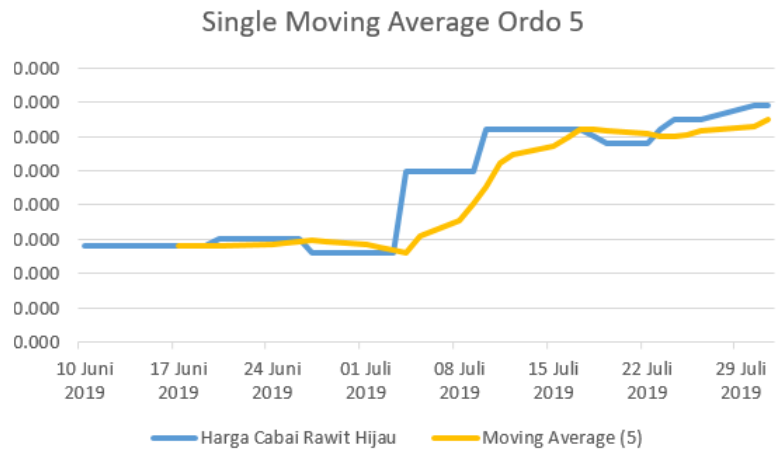

Gambar 2. Perbandingan data observasi dengan hasil peramalan berorde 5

Terlihat hasil output masing-masing metode berorde berbeda dibandingkan dengan data observasi. Sekilas dari ke kedua metode tersebut hampir sama sehingga untuk model yang terbaik dapat dilihat dari accuracy measures pada masing-masing plot tersebut. Pada Tabel 2 di tunjukan sample hasil nilai eror asli peramalan dari masing-masing metode yang digunakan sebagai bahan perbandingan.

\begin{tabular}{ccc}
\multicolumn{3}{c}{ Tabel 2. Sample data eror } \\
\hline Periode & Orde 10 & Orde 5 \\
\hline 04 Juli 2019 & 22.200 & 24.000 \\
05 Juli 2019 & 20.000 & 19.200 \\
08 Juli 2019 & 18.000 & 14.400 \\
09 Juli 2019 & 16.000 & 9.600 \\
10 Juli 2019 & 26.000 & 16.800 \\
11 Juli 2019 & 22.800 & 9.600 \\
12 Juli 2019 & 19.200 & 7.200 \\
15 Juli 2019 & 15.600 & 4.800 \\
16 Juli 2019 & 12.000 & 2.400 \\
17 Juli 2019 & 8.400 & 0.000 \\
\hline
\end{tabular}

Berdasarkan hasil nilai eror asli peramalan dari masing-masing metode, dapat dilihat pada tabel 3 
bahwa ordo yang terbaik dapat di lihat dari nilai error seperti nilai $e_{t}$, MSE dan RMSE mengindikasi seberapa besar kesalahan dalam meramal dibandingkan dengan nilai nyata, sedangkan MSE sendiri mengatur kesalahan peramalan yang besar karena kesalahan-kesalahan itu di kuadratkan. Berdasarkan output di atas di peroleh bahwa metode single moving average berordo 5 memiliki nilai eror yang paling kecil di antara yang lain. Sehingga ordo 5 peramalannya lebih baik dari ordo 10.

Tabel 3 Hasil Perhitungan Eror

\begin{tabular}{ccc}
\hline Kriteria & Ordo 10 & Ordo 5 \\
\hline $\mathbf{e}_{\mathrm{t}}$ & 199.600 & 118.200 \\
$\boldsymbol{M S E}$ & 7.677 & 3.813 \\
$\boldsymbol{R M S E}$ & 14.12799 & 10.87198
\end{tabular}

\section{KESIMPULAN DAN SARAN}

\subsection{Kesimpulan}

Kesimpulan dari pembahasan diatas antara lain: 1. Pada metode Single Moving Average berordo 10 didapatkan nilai e 199.600, MSE 7.677 dan RMSE 14.12799.

2. Pada metode Single Moving Average berordo 5 didapatkan nilai e 118.200, MSE 3.813 dan RMSE 10.87198 .

3. Dari penjelasan di atas antara dua metode yang digunakan dalam peramalan harga cabai di Kota Semarang dengan mengunakan metode Single Moving Average berordo 5 dan Single Moving Average berordo 10, terbukti bahwa metode Single Moving Average berordo 5 lebih baik dibandingkan dengan metode Single Moving Average berordo 10.

\subsection{Saran}

Pada penelitian ini hanya berfokus menggunakan metode Single Moving Average dengan ordo yang berbeda. Pada penelitian selanjutnya dapat dikembangkan dengan membandingkan metode Single Moving Average dengan metode yang lain.

\section{DAFTAR PUSTAKA}

D. Sukmawati., 2014. Fluktuasi Harga Cabai Merah Keriting (Capsicum annum L) di Sentra Produksi dan Pasar Induk. Bali : ICBESS

Musrhalis, Alex. 2007. Peramalan dan Faktorfaktor Penentu Fluktuasi Harga Cabai Merah di Enam Kota Besar Di Jawa - Bali. Program Sarjana Ekstensi Manajemen Agribisnis Fa.kultas Pertanian Institut Pertanian Bogor.

Huffaker R, Canavari M, Muñoz-Carpena R. 2016. Distinguishing between endogenous and exogenous price volatility in food security assessment: an empirical nonlinear dynamics approach. Agric Syst [Internet]. [cited 2020 Dec 5]; 160:98-109. Tersedia melalui:

https://ac.elscdn.com/S0308521X16305893 /1-s2.0-S0308521X 16305893main.pdf?_tid=b8f6b5b2-b79c-11e7-92 5900000aacb360\&acdnat $=1508727124 \_1940$ 5d6 ac374e2f594f8705ba90378b1 doi:10.1016/j.agsy. 2016.09.019.

Hadiansyah, F. N. 2017. Prediksi Harga Cabai dengan Menggunakan Pemodelan Time series ARIMA. Indonesian Journal on Computing (Indo-JC), 2(1), 71-78.

Prapcoyo, H., 2016, Peramalan Jumlah Mahasiswa Menggunakan Moving Average. Telematika Vol 15, 6675

Solikin, I., 2016, Sistem Informasi Peramalan Pembelian Stok Barang Menggunakan Metode Single Moving Average(SMA). Jurnal Cendekia Vol 12, 18-22 